\title{
Revision of the Madagascan endemic Homollea (Rubiaceae - Pavetteae), with description of two new species
}

\author{
Petra DE BLOCK \\ Botanic Garden Meise, Nieuwelaan 38, B-1860 Meise, Belgium. \\ Email: petra.deblock@botanicgardenmeise.be
}

\begin{abstract}
Homollea Arènes (Rubiaceae, subfamily Ixoroideae, tribe Pavetteae) is a genus of shrubs and small trees endemic to western and northern Madagascar. The genus comprises five species occurring in dry deciduous forest, often in limestone areas. The five species are narrow endemics and their conservation status is either Endangered (4 species) or Critically Endangered (1 species). Homollea is characterized by few-flowered, pseudo-axillary, pedunculate inflorescences, well-developed calyces with the lobes much longer than the tube, laterally flattened seeds with a shallow, elongated to linear hilum and entire endosperm, ovules arising from the upper margin of the placenta, and, pollen grains with supratectal elements in the shape of microgemmae. Until now, three species were known and their descriptions are amended. Two further species, $H$. furtiva De Block sp. nov. and $H$. septentrionalis De Block sp. nov., are described as new for science. The five species are dealt with in detail: descriptions, distribution maps, conservation assessments, illustrations, lists of exsiccatae and an identification key are given.
\end{abstract}

Keywords. Identification key, Madagascar, new species, pyrene morphology, taxonomy.

De Block P. 2018. Revision of the Madagascan endemic Homollea (Rubiaceae - Pavetteae), with description of two new species. European Journal of Taxonomy 423: 1-24. https://doi.org/10.5852/ejt.2018.423

\section{Introduction}

Madagascar boasts an extremely rich and unusually diverse as well as a highly endemic flora. Endemicity is especially high at species level (> 80\%), but much lower at genus level (19\%) (Callmander et al. 2011). With ca 800 species (Govaerts et al. 2016) the Rubiaceae are the second largest family of flowering plants (after Orchidaceae) and comprise the second largest number of endemic species (again after Orchidaceae). Endemicity at species level is $92 \%$ (Callmander et al. 2011), which is higher than for the vascular flora as a whole. This is also the case for the rate of endemicity at genus level. At the time of writing (end 2016), 91 described Rubiaceae genera (Ferm et al. 2016; Govaerts et al. 2016) are present in Madagascar, of which 30 are endemic to the island and five further ones endemic to Madagascar and the Comoros (Govaerts et al. 2016; Ferm et al. 2016), which is equivalent to $33 \%$ and $38.5 \%$ of endemicity at genus level, respectively (vs 19\% for the vascular flora as a whole). These rates are bound to become higher still as new genera continue to be described. 
Unfortunately, Madagascar is not only known for great species richness and high endemicity, but also for the rapid destruction of its natural habitats. In 2007, Moat \& Smith calculated that only $18 \%$ of primary vegetation remains in Madagascar, resulting in habitat loss for both plant and animal species and rendering them more vulnerable to extinction (Moat \& Smith 2007). This is especially pertinent for the Rubiaceae since the family is still poorly known taxonomically and we run the risk of losing species before we have been able to formally describe them. An analysis of taxonomic effort (Davis et al. 2009) showed that, worldwide, the number of new Rubiaceae species described each year has not decreased markedly in recent years. For Madagascan Rubiaceae, recent years have in fact seen a spectacular increase in the description of new species. Since 2000, 125 new Rubiaceae species were described for Madagascar vs 28 species from 1980 till 1999 (data analysed in December 2016 from Govaerts et al. 2016 and from The International Plant Names Index (IPNI) 2012). Many of these newly described species are based on recently collected plant material, e.g., Coffea toshii A.P.Davis \& Rakotonas. (Davis et al. 2010) and Ixora fuscovenosa De Block (De Block 2014), collected in 2006 and 2005 for the first time, respectively.

The tribe Pavetteae (subfamily Ixoroideae) accounts for ca 10\% of the 800 Madagascan Rubiaceae species. Even though only 80 species occur on the island (vs ca 340 species in continental Africa and ca 240 in Asia), Madagascar is a centre of diversity for the tribe, because the Madagascan Pavetteae are very diverse in morphology and represent a high number of lineages, often with only a few species. The Madagascan Pavetteae are especially variable in fruit, seed and placentation characters, which usually are more conservative at tribal level. Many Madagascan Pavetteae species but also some genera are as yet undescribed. Currently, the Madagascan Pavetteae comprise the following genera: Coptosperma Hook.f. (= Enterospermum Hiern), Homollea Arènes, Paracephaelis Baill. (including Homolliella Arènes; De Block et al. 2015), Robbrechtia De Block, Schizenterospermum Homolle ex Arènes and Tarenna Gaertn. The Madagascan Pavetteae share the characters of the tribe: woody habit, entire stipules (but fimbriate in Rutidea DC.), terminal inflorescences (but rarely axillary, e.g., in the Afro-Madagascan Coptosperma supra-axillare (Hemsl.) Degreef), contorted aestivation, stigmatic lobes fused over most of their length (but stigma bilobed in Robbrechtia De Block), drupaceous fruits, seeds with an adaxial excavation often surrounded by a thickened ring, endosperm entire or ruminate, exotestal cells parenchymatous or with thickenings along the outer tangential wall, 3- or 4-colporate tectate pollen grains and secondary pollen presentation.

The genus Homollea comprises shrubs and, more rarely, small trees up to $5 \mathrm{~m}$ tall from the dry deciduous forests of northern and western Madagascar. The majority of the species occur on limestone. Homollea is characterized by sheathing stipules, coriaceous or subcoriaceous leaves, few-flowered, pseudo-axillary, pedunculate inflorescences, well-developed calyces with the lobes much longer than the tube, laterally flattened seeds with a shallow, elongated to linear hilum and entire endosperm, ovules arising from the upper margin of the placenta, and, pollen grains with supratectal elements in the shape of microgemmae (De Block \& Robbrecht 1998). Within the Pavetteae this combination of characters is only found in Homollea and two other Madagascar-centred genera Homolliella and Paracephaelis. Homollea and Homolliella were published at the same time by Arènes (1960), based on notes by Homolle, who had identified them as new but was unable to complete their publication. Paracephaelis had been described eighty years earlier as a monospecific genus (Baillon 1879).

In his unpublished manuscript on the Rubiaceae of Madagascar and the Comores, Capuron (1973) incorporated Homollea, Homolliella and Paracephaelis in the genus Tarenna. Within the modern concept of the tribe Pavetteae, Capuron recognized only two genera: Enterospermum (current name Coptosperma, see De Block et al. 2001), characterized by seeds with ruminate endosperm, and Tarenna, characterized by seeds with entire endosperm. Capuron was well aware of the great variation in seed structure and placentation in his genus Tarenna and recognized five sections, three of which concern 
species with laterally flattened seeds with shallow elongated hilum, i.e., Homollea, Homolliella and Paracephaelis. Recently, a first phylogenetic study of the tribe Pavetteae was published (De Block et al. 2015). Despite a largely unresolved phylogeny for the Afro-Madagascan clade due to low sequence divergence, Homollea was shown to be monophyletic, as was Paracephaelis after the inclusion of Homolliella. Homollea is easily distinguished from Paracephaelis (including Homolliella) by the pseudo-axillary, pedunculate and few-flowered inflorescences (vs terminal, (sub)sessile and usually multiflorous) and by the longer calyx lobes (4.5-25 mm vs 1-4 mm long). De Block et al. (2015) also showed that Homollea and Paracephaelis do not belong to the same subclade as the Madagascan Tarenna. Therefore, these genera should not be included in Tarenna but deserve recognition at genus level.

The genus Homollea is undercollected, with less than fifty specimens for five species. This results in a certain degree of uncertainty regarding the descriptions, which are based on relatively few specimens. This is especially problematic for flower and fruit characters, since mature flowers and fruits are rare within the collected material.

As mentioned above, the Madagascan Pavetteae show great variation in their fruit and seed characters. While fruits are always fleshy, the endocarp is thin and crustaceous or thick and stony, the number of pyrenes either one or two, the number of seeds one to ca ten, the seed shape angular, spherical, hemispherical or laterally flattened, the hilum profound or shallow and round or elongated, the endosperm entire or ruminate and the exotesta cells parenchymatous or with thickenings along the outer tangential wall. While studying the fruits of Homollea, great variation was found in the structure of the endocarp. Thin, crustaceous pyrenes occur in certain species while others are characterized by stony pyrenes which open along preformed germination slits. Unique within the Pavetteae is the formation of dispersal units which consist of part of the pyrene wall and part of the septum.

This paper is part of a series dealing with the Madagascan representatives of the Pavetteae (e.g., De Block et al. 2001; De Block 2003a, 2003b). The overall objective of this series is to clarify the generic delimitations and phylogenetic relationships within this group. Recent revisions of Madagascan Pavetteae are mostly inexistent and many species remain undescribed. In this context, this revision of Homollea summarizes and updates all known data on this genus endemic to Madagascar, and describes two new species.

\section{Material and methods}

All material cited was seen, except when stated otherwise. Herbarium specimens of the following institutions were studied: BR, G, K, MO, P, S, TAN, TEF and WAG; herbarium acronyms follow Index Herbariorum (Thiers continuously updated). Methods follow normal practice of herbarium taxonomy (Leenhouts 1968). Vegetative characters are described based on herbarium material, e.g., colour of leaf blades, leaf size, shapes of sections (e.g., of young shoots, petioles and peduncle); description and sizes of flowers and fruits cover the range of dried and alcohol-preserved material and their colours are given for living material. In the absence of flowers, certain characters such as size and shape of the ovary, the calyx tube and the calyx lobes have been scored on very young or aborted fruits. Flowering and fruiting periods are based on dates given on the labels of the herbarium material.

Terminology generally follows Robbrecht (1988): e.g., as opposed to the definitions in Beentje (2012), the 'calyx' is here considered to comprise the upper portion of the outermost floral whorl from where it becomes free from the hypanthium; 'calyx tube' is the fused basal part of this structure; 'calyx lobes' are the free sepals. However, leaf shape is described according to the terminology of simple symmetrical plane shapes (Anonymous 1962). Robbrecht (1988) does not detail terminology for bracts. In Homollea, as in many Pavetteae, the first order bracts (the pair of bracts supporting the entire inflorescence) are foliaceous. They are described here as consisting of stipular and foliar parts, i.e., the parts that are in the 
same position as the stipules and the leaves on a vegetative node, respectively. In Homollea the stipular parts form small sheaths, the foliar parts are actual blades with a short petiole.

Plant material studied is listed per province and per region, alphabetically per collector. Localities are cited as given by the collectors on the specimen labels, but regions have been added in order to reflect the new administrative division of the country. If no GPS coordinates were available, coordinates of localities were determined using the online Gazetteer to Malagasy Botanical Collecting Localities (Schatz et al. 2003). Additionally, 1:500.000 maps from the Malagasy Institut National de Géodésie et Cartographie were used. Distribution maps were drawn using Arcmap 9.2. The conservation status was assessed by applying the IUCN Red List Category criteria (IUCN 2001, 2016) using GeoCAT (Geospatial Conservation Assessment tool; Bachman et al. 2011). In order to compensate for the inadequate level of sampling for the genus Homollea, cell size has been chosen at $3 \times 3 \mathrm{~km}$, rather than the $2 \times 2 \mathrm{~km}$ cell size suggested by IUCN for most taxa (Callmander et al. 2007). The IUCN category Data Deficient (DD) was avoided since it tends to underestimate the number of threatened species (Callmander et al. 2005, 2007).

Abbreviations used: coll. ignot. $=$ collector unknown; $\mathrm{fl}=$ flowers; $\mathrm{fr}=$ fruits; $\mathrm{n} . \mathrm{v} .=$ non vidi; scan $=$ specimen scan provided by institution or person; vs = versus .

\section{Results}

\section{Homollea Arènes}

Notulae Systematicae 16: 15, f. 3 (Arènes 1960).

\section{Type species}

Homollea longiflora Arènes.

\section{Description}

Shrubs or small trees; vegetative and reproductive parts glabrous or pubescent (externally); young shoots quadrangular with concave sides or flattened and bisulcate (when dry). Leaves decussate, shortly petiolate; petioles canaliculate above; blades coriaceous or subcoriaceous; margin (somewhat) revolute when dry; domatia present or absent; venation brochidodromous; midrib somewhat impressed above (at the leaf base), raised below; secondary veins somewhat raised above, raised below; higher order veins somewhat raised above; stipules interpetiolar, sheathing, sheats keeled, basally fused into a cone (1-5 mm long) with upper free parts (1-5 mm long) triangular with acute tips or ovate with acuminate tips, adaxial surface glabrous but with a continuous row of large $(1-1.5 \mathrm{~mm}$ long) colleters, sometimes interspaced with a few hairs, at the base. Inflorescences pseudo-axillary, pedunculate, cymose, compact, consisting of 1-12 flowers; peduncle, axes, pedicels and bracts green; peduncle $0.5-13.5 \mathrm{~cm}$ long, quadrangular with concave sides or flattened and bisulcate (when dry); first order bracts with stipular parts consisting of small sheaths and foliar parts consisting of modified leaves; higher order bracts absent or strongly reduced; bracteoles absent. Flowers sessile or shortly pedicellate, 5-merous, hermaphrodite; calyx well developed, green; calyx tube $1-2.5 \times 1.5-2.5 \mathrm{~mm}$; calyx lobes much longer than tube, linear to narrowly spathuliform; corolla narrowly tubular (1-1.5 mm wide) but widening in the upper $5 \mathrm{~mm}$ below the throat, white; corolla lobes contorted to the left in bud and spreading at anthesis; stamens sessile, inserted in the corolla tube somewhat below the level of the throat, included for 1-4 $\mathrm{mm}$ in the corolla tube at anthesis; anthers linear, basimedifixed, sagittate, with sterile apical appendix to ca $0.5 \mathrm{~mm}$ long; disc annular, fleshy, glabrous; ovary cupular, $1-2 \times 1.5-2 \mathrm{~mm}$, bilocular; placentation axile; placentas peltate, attached at or somewhat below the middle of the septum, with 2-7 ovules arising from the upper margin of the placenta; style and stigma white; style slender, glabrous; stigma partly exserted at anthesis, slender; stigmatic lobes fused over their entire length, papillae situated along the lines of 
fusion of the stigmatic lobes; secondary pollen presentation present. Fruits drupaceous, spherical or subspherical, usually somewhat wider than high (not including calyx), not exceeding $1 \mathrm{~cm}$ in diameter, glossy and often strongly wrinkled in dried state, with persistent calyx, colour unknown (indicated as green on collector labels, only once suggested to be yellow or orange at maturity); exocarp glabrous or pubescent; mesocarp with well-developed vascular bundles; endocarp forming 2 hemispherical or hemi-ovate pyrenes which remain joined adaxially, either thin and crustaceous and without opening mechanism, or stony and breaking up along 4 preformed germination slits, rarely with the formation of separate stony dispersal units each including a single seed; seeds 1-3 per pyrene, (1-)2-6 per fruit, laterally compressed, reddish brown, hilar cavity shallow, elongated to linear; endosperm entire; embryo with foliaceous cotyledons; radicle inferior. Seed-coat thickened along the outer tangential wall and the upper parts of the radial walls; thickenings continuous but for a narrow ring-like intrusion from the cell lumen, visible in longitudinal section as two narrow canals running down from the outer edges of the cells; exotesta cells somewhat elongated around the hilum, but thickenings not taking part in the elongation; cell lumina filled with tannins (De Block 1997; see also Bridson \& Robbrecht 1985: f. 8, depicted for Paracephaelis trichantha (Baker) De Block, as Tarenna trichantha (Baker) Bremek.)). Pollen grains 3-zonocolporate; exine microreticulate to perforate, microgemmae present.

\section{Distribution}

Homollea is a genus of five species endemic to northern (Diana and Sava Regions, Antsiranana Province) and western Madagascar (Betsiboka, Boeny, Bongolava and Melaky Regions, Mahajanga Province). The species occur in lowland dry semideciduous or deciduous forest, on sandy soil or on limestone.

\section{Identification key to the species of Homollea}

1. Plants glabrous (young shoots, stipules and leaves, inflorescence, ovary, calyx, corolla and fruit); calyx tube glabrous inside

- Plants moderately to densely pubescent (young shoots, stipules and leaves, inflorescence, ovary, calyx, corolla and fruit); calyx tube pubescent inside

2. Bark of older shoots fawn or pale beige

H. leandrii Arènes

- Bark of older shoots reddish brown

3. Leaves narrowly elliptic or narrowly ovate, $(5.5-) 7-12 \times(1.3-) 1.7-3(-4) \mathrm{cm}$; domatia often absent; inflorescence 3-12-flowered; blades of first order bracts linear, narrowly elliptic, narrowly ovate or, more rarely, ovate, with attenuate bases and petioles $3-6 \mathrm{~mm}$ long; pedicels $2-8 \mathrm{~mm}$ long; calyx lobes not ciliate at the base outside; secondary veins 7-12 on each side of midrib .. H. longiflora Arènes

- Leaves broadly obovate or broadly elliptic, rarely obovate, elliptic or ovate, 4-7 $\times 2.5-4 \mathrm{~cm}$; ciliate pit domatia present; inflorescences 1-3-flowered; blades of first order bracts broadly ovate, with cordate or truncate bases and petioles $0-1 \mathrm{~mm}$ long; pedicels to $2 \mathrm{~mm}$ long; calyx lobes sparsely ciliate at the base outside (trichomes usually absent in fruiting stage); secondary veins 4-6(-7) on each side of midrib H. furtiva De Block sp. nov.

4. Bark of older shoots fawn, greyish or dull brown, never reddish brown; young shoots, leaves and inflorescence parts pubescent with trichomes up to $0.5 \mathrm{~mm}$ long; leaves narrowly elliptic, narrowly obovate, linear or, more rarely, elliptic or obovate; first order bracts with shortly petiolate, linear, elliptic or ovate blades with cuneate to attenuate base; calyx lobes $5-8(-10) \mathrm{mm}$; corolla tube $15-20 \mathrm{~mm}$ long; corolla lobes $8-11 \mathrm{~mm}$ long; $2-3$ ovules per locule

H. perrieri Arènes

- Bark of older shoots reddish brown; young shoots, leaves and inflorescence parts pubescent with trichomes (0.3-)0.5-1.5 mm long; leaves elliptic or, more rarely, ovate or obovate; first order bracts with sessile or subsessile, broadly ovate or ovate blades with cordate or truncate base; calyx lobes (9-12-)17-25 mm long; corolla tube 20-27 mm long; corolla lobes 13-18 mm long; 4-6 ovules per locule

H. septentrionalis De Block sp. nov. 


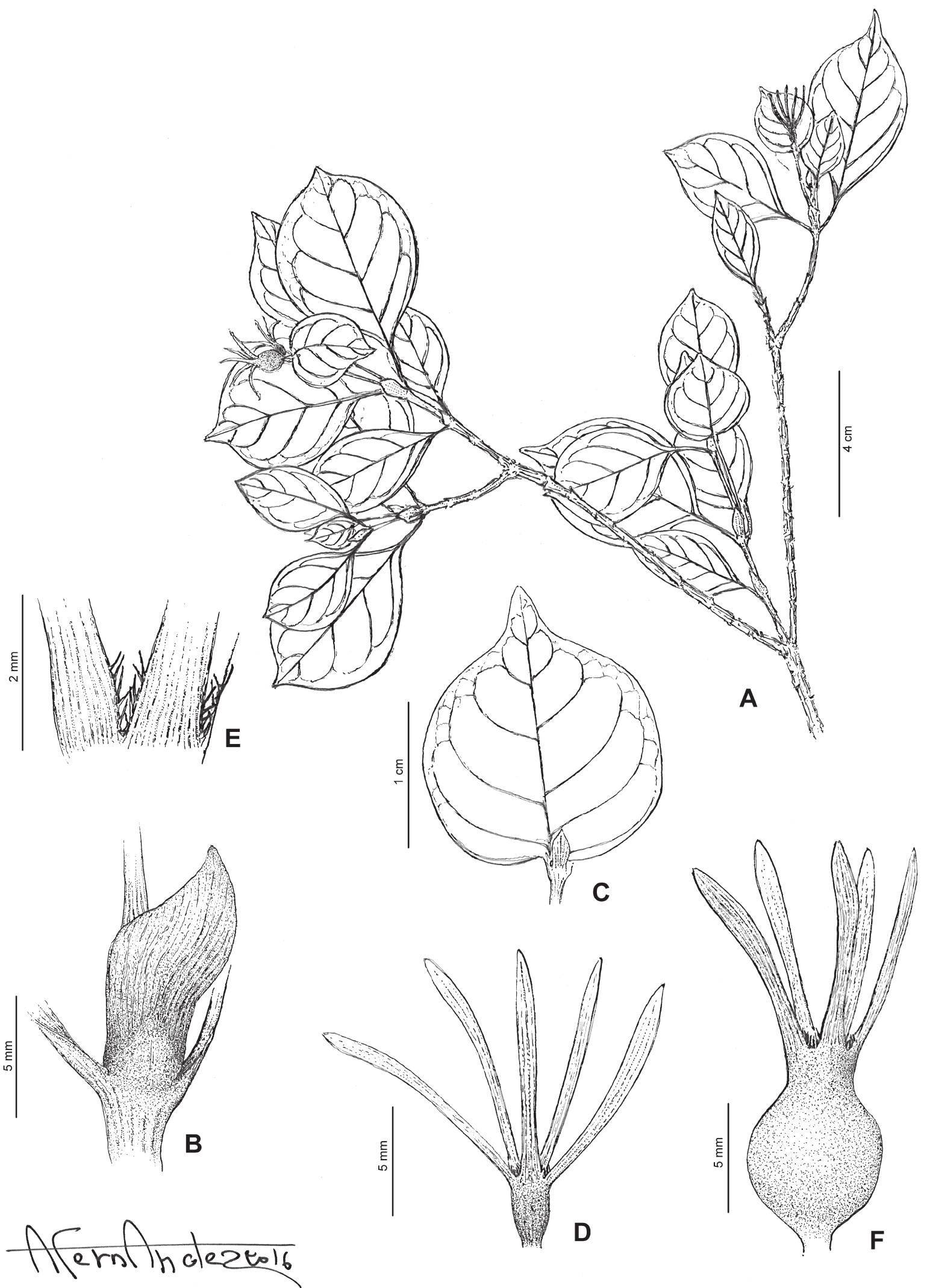

Fig. 1. Homollea furtiva De Block sp. nov. A. Fruiting branch. B. Stipule. C. First order bract. D. Ovary and calyx. E. Detail of D showing the sparsely ciliate base of the calyx lobes. F. fruit. Drawn by Mr. A. Fernandez. From Razafitsalama et al. 583 (MO). 
Homollea furtiva De Block, sp. nov. urn:Isid:ipni.org:names:77177485-1

Figs 1, 6A

\section{Diagnosis}

Resembling $H$. longiflora Arènes and $H$. leandrii Arènes because of the glabrous vegetative and reproductive parts, but differing from both species by the inflorescences with fewer flowers (1-3 vs $3-12$ ); similar to $H$. longiflora because of the reddish brown shoots but differing from this species by the shape and size of the vegetative leaves (broadly obovate, broadly elliptic, or, rarely obovate, elliptic or ovate, $4-7 \times 2.5-4 \mathrm{~cm}$ vs narrowly elliptic or narrowly ovate, $(5.5-) 7-12 \times(1.3-) 1.7-3(-4) \mathrm{cm})$ and the number of secondary veins on each side of the midrib (4-6(-7) vs 7-12); similar to H. leandrii because of the calyx lobes which are sparsely ciliate at their bases and the shape of the blades of the first order bracts (broadly ovate or ovate with cordate to truncate base), but differing from this species by the reddish brown shoots (vs fawn or pale beige).

\section{Etymology}

The specific epithet comes from the Latin adjective furtivus (secret, clandestine). It refers to the fact that the species was only recently collected for the first time.

\section{Type material}

Madagascar, Antsiranana Province, Diana Region, commune Mahavanona, fokontany Andranomanitra, Montagne des Français, vers 5 km NE d'Andranomanitra, 325 m, 29 Mar. 2004 (fr), Razafitsalama, Ratovoson, Randrianasolo, Rakotondrajaona, Jullet, Rasolofo, Flavien \& Tombondrainy 583 (holo-: $\mathrm{MO}$; iso-: $\mathrm{K}, \mathrm{P}$ ).

\section{Other material studied}

MADAGASCAR: Antsiranana Province: Diana Region, Montagne des Français, forêt d'Antaolanaomby, 385 m, 22 Mar. 2007 (fr), Ratovoson, Benjara \& Jaovoavy 1279 (CNARP n.v., MO scan, P n.v., TAN n.v.).

\section{Description}

Small shrub, ca $2 \mathrm{~m}$ tall; vegetative and reproductive parts glabrous (externally); young shoots smooth, brown; older shoots reddish brown, flaking. Leaves with petioles $0.5-1.2 \mathrm{~cm}$ long; blades broadly obovate or broadly elliptic, rarely obovate, elliptic or ovate, $4-7 \times 2.5-4 \mathrm{~cm}$, thinly coriaceous, drying somewhat glossy and brown or greenish brown above, paler below; apex acuminate, acumen $0.3-1.2 \mathrm{~cm}$ long; base attenuate; secondary veins $4-6(-7)$ on each side of midrib; ciliate pit domatia present; stipules $0.5-0.8 \mathrm{~cm}$ long, basal cone $2-4 \mathrm{~mm}$ long, free parts of sheaths $1.5-4 \mathrm{~mm}$ long, triangular with acute, obtuse or somewhat rounded tips, or, ovate with acuminate tips, acumen up to $2 \mathrm{~mm}$ long. Inflorescences 1-3-flowered; peduncle 2-4 cm long; first order axes up to $3 \mathrm{~mm}$ long but mostly absent; first order bracts consisting of 3-4 $\mathrm{mm}$ high, ovate sheaths and blades broadly ovate, $1-3.5 \times 1-3 \mathrm{~cm}$ with cordate or truncate bases and petioles up to $1 \mathrm{~mm}$ long; higher order bracts and bracteoles absent. Flowers shortly pedicellate, pedicels up to $2 \mathrm{~mm}$ long; calyx tube $1-1.5 \mathrm{~mm}$ long, glabrous and without colleters inside; calyx lobes $10-15 \times$ ca $1 \mathrm{~mm}$, sparsely ciliate at the base outside (trichomes usually absent in fruiting stage), glabrous inside, tips obtuse to acute; corolla, style and stigma and anthers unknown; ovary ca $2 \mathrm{~mm}$ long; 4-7 ovules per locule. Fruits at least ca $6 \times 6 \mathrm{~mm}$ (persistent calyx not included); pyrenes thin, crustaceous; septum not stony; seeds $2-6$ per fruit, $3-5 \times 2.5-3 \mathrm{~mm}$. 


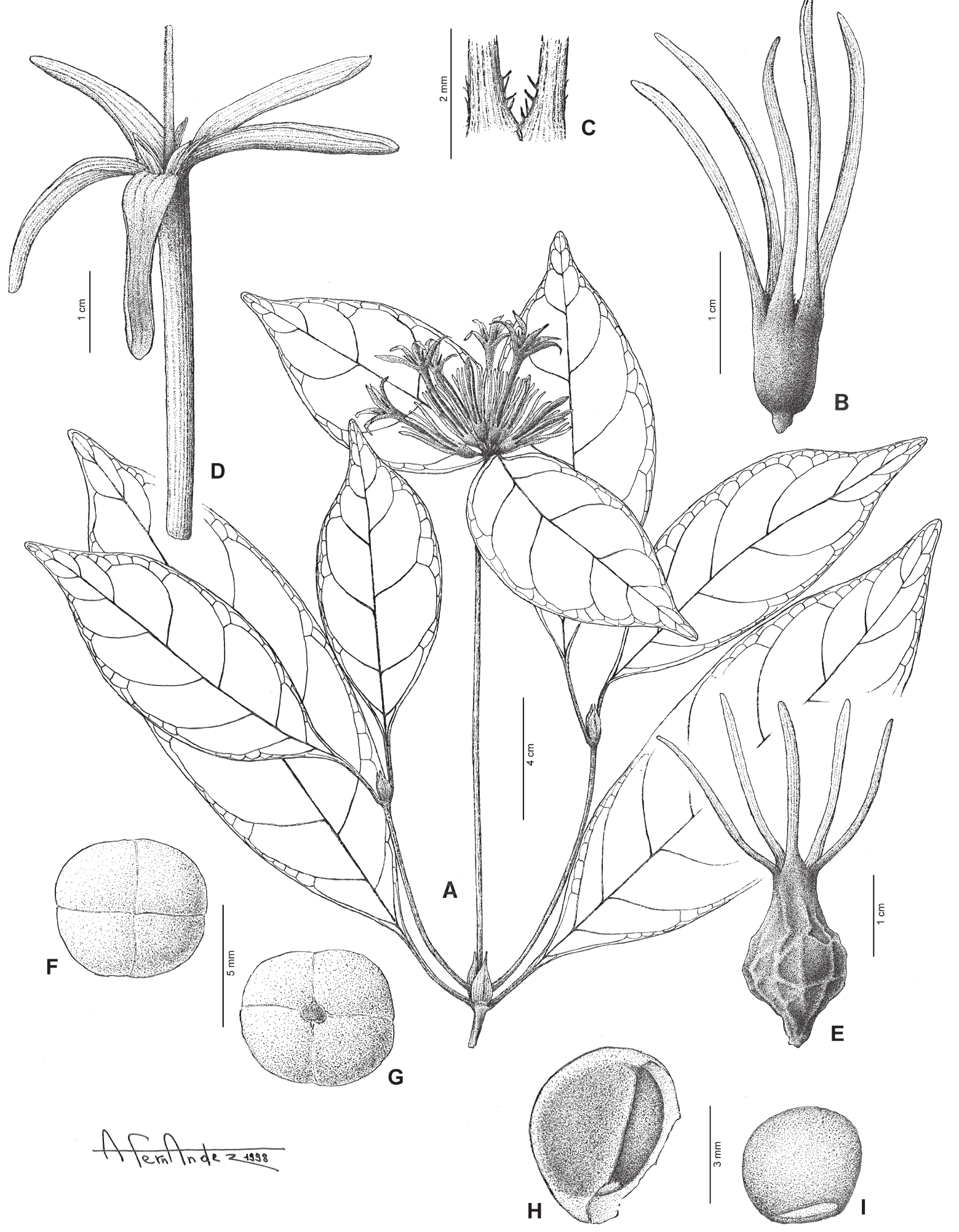

Fig. 2. Homollea leandrii Arènes. A. Flowering branch. B. Ovary and calyx. C. Detail of B showing the sparsely ciliate base of the calyx lobes. D. Corolla, stamens, style and stigma. E. Fruit. F. Pyrene, apical view. G. Pyrene, basal view. H. Dispersal unit, adaxial view. I. Seed, lateral view. Drawn by Mr. A. Fernandez. A-C from Leandri 2094 (P); D from coll. ignot. 4680-RN (P); E from Leandri 884 (P); F-I from Andriambololonera et al. 171 (BR). 


\section{Distribution}

Only known from Montagne des Français, a limestone massif close to Antsiranana in the Diana Region (Antsiranana Province) in North Madagascar (Fig. 6A).

\section{Habitat and phenology}

Lowland dry semideciduous or deciduous forest; on limestone. Fruiting: March.

\section{IUCN status}

Critically Endangered: CR B2ab(iii). Since only two specimens of $H$. furtiva sp. nov. are known, the extent of occurrence (EOO) could not be calculated. Its area of occupancy (AOO) is estimated to be $18 \mathrm{~km}^{2}$ using a cell width of $3 \mathrm{~km}$. The two known specimens are recent and were collected after the year 2003. All the collecting sites fall within the Montagne des Français New Protected Area (created in 2013). However, protection of the Montagne des Français is weak and its dry forests are under threat by logging for timber and charcoal for the population of the city of Antsiranana. With a very limited geographic range, threats which lead to infer a continuing decline in the quality of habitat, and a single location, $H$. furtiva sp. nov. is assessed as Critically Endangered (CR).

\section{Notes}

Homollea furtiva sp. nov. has only been collected twice. Flowers are unknown.

This species combines characters from both H. leandrii (calyx lobes sparsely ciliate at the base; broadly ovate leaves subtending the inflorescences) and H. longiflora (reddish brown shoots).

\section{Homollea leandrii Arènes}

Figs 2, 6A

Notulae Systematicae 16: 15, f. 3 (9-13) (Arènes 1960). - Type: Madagascar, Mahajanga Province, Melaky Region, district Antsalova, Réserve Naturelle Intégrale de Bemaraha, 8 Dec. 1952 (fl), coll. ignot. 4680-RN (holo-: P; iso-: P, TAN, TEF).

\section{Other material studied}

MADAGASCAR: Mahajanga Province: Melaky Region, Parc National de Bemaraha, 50-135 m, 10 Jul. 2006 (fr), Andriambololonera, Ramelison, Rakotonasolo, Andriamanampandry \& Lanne 171 (BR, MO, P); district Antsalova, National Park Tsingy de Bemaraha, near Ambodiria, route to Tsiandro, before Bevary, 115 m, 18 Mar. 2004 (fr), Davis \& Rakotonasolo 3132 (BR, K, TAN); Réserve Naturelle Intégrale de Bemaraha, Tsiandro, 10-12 Feb. 1953 (fr), Leandri 884 (P); aux environs de Tsiandro, 500 600 m, 25 Nov.-3 Dec. 1952 (fl), Leandri, Capuron \& Razafindrakoto 1978 (P); forêt de l'Antsingy, vers Ambodiriana, E d'Antsalova, 100-150 m, 9-10 Dec. 1952 (fl), Leandri, Capuron \& Razafindrakoto 2094 (BR, P, MO); forêt de Tsiampihy, près de la Réserve Naturelle Intégrale de Bemaraha, 0-20 m, 19 Dec. 1952-2 Jan. 1953 (fl), Leandri, Capuron \& Razafindrakoto 2215 (P); calcaires de l'Antsingy, vers Ambodiriana, E d'Antsalova, 100-150 m, 21-27 Jan. 1960 (fl), Leandri \& Saboureau 2757 (BR, G, K, MO, P); calcaires de l'Antsingy, vers Ambodiriana, E d'Antsalova, 100-150 m, 21-27 Jan. 1960 (fl), Leandri \& Saboureau 2764 (P); Beanka, partie centrale, Ambinda-Nord, 227 m, 12 Feb. 2012 (fl), Rakotozafy, Bolliger \& Hanitrarivo 48 (BR, G).

\section{Description}

Small shrub, 2-3 m tall; vegetative and reproductive parts glabrous (externally); young shoots brown, smooth; older shoots fawn or pale beige, glossy, flaking. Leaves with petioles $0.5-1.5 \mathrm{~cm}$ long; blades elliptic, ovate or obovate, $5-12.5 \times 2-5 \mathrm{~cm}$, coriaceous, drying glossy and green or brownish above, 
glossy and somewhat paler below; apex acuminate, acumen 0.4-1.2 cm long; base attenuate; secondary veins 5-10 on each side of midrib; ciliate pit domatia present; stipules $0.6-1 \mathrm{~cm} \mathrm{long}$, basal cone $2.5-5 \mathrm{~mm}$ long, free parts of sheaths $2-4.5 \mathrm{~mm}$ long, ovate with acuminate tips, acumen 1-2 mm long. Inflorescences 3-12-flowered; peduncle 2-12 cm long; first order axes up to $2 \mathrm{~mm}$ long but often absent; first order bracts consisting of $1.5-4 \mathrm{~mm}$ high, broadly ovate or broadly triangular, keeled sheaths with acuminate tips and blades ovate or broadly ovate, $(1.2-) 2-6.5 \times 1-3.5 \mathrm{~cm}$ with rounded to truncate bases and 1-3 mm long petioles; higher order bracts usually absent, if present, then strongly reduced, triangular, up to $0.5 \mathrm{~mm}$ long; bracteoles absent. Flowers shortly pedicellate, pedicels up to $2 \mathrm{~mm}$ long; calyx tube 1-2 mm long, glabrous and without colleters inside; calyx lobes (6-)8-12 $\times$ $0.5-1.5 \mathrm{~mm}$, sparsely ciliate at the base outside (trichomes usually absent in fruiting stage), glabrous inside, tips obtuse to rounded; corolla tube (6-)23-26 mm long, densely villose in the upper third inside; corolla lobes $8-13 \times 2-3 \mathrm{~mm}$, tips obtuse to rounded; anthers $4-5.5 \mathrm{~mm}$ long, exserted for ca $3 \mathrm{~mm}$ from corolla tube at anthesis, inserted ca $0.5 \mathrm{~mm}$ below the level of the throat; ovary $1.25-1.5 \mathrm{~mm}$ long, sometimes faintly ribbed longitudinally (when dry); (2-)3 ovules per locule; stigma exserted from corolla tube for (3-)6-11 mm at anthesis, receptive zone 10-16 mm long. Fruits 5-7.5 $\times 6.5-8 \mathrm{~mm}$ (persistent calyx not included); pyrenes stony, with four longitudinal preformed germination slits (two along the lines of fusion of the two locules and two perpendicular to those), breaking up into individual dispersal units (ca 4) formed by part of the pyrene wall and part of the stony septum, each containing a single seed; seeds ca 4 per fruit, ca $3 \times 3.5 \mathrm{~mm}$.

\section{Distribution}

Known from the Melaky Region in western Madagascar (Mahajanga Province): only collected in the vicinity of Antsalova and Tsingy de Bemaraha (Fig. 6A).

\section{Habitat and phenology}

Lowland dry semideciduous or deciduous forest, on limestone, alt. 0-600 m. Flowering: DecemberJanuary; fruiting: February-July.

\section{IUCN status}

Endangered: EN B1ab(i,ii,iii,iv,v) + 2ab (i,ii,iii,iv,v). The extent of occurrence (EOO) of H. leandrii is estimated to be $4,160 \mathrm{~km}^{2}$, and its area of occupancy (AOO) $63 \mathrm{~km}^{2}$ using a cell width of $3 \mathrm{~km}$. Most of the specimens of this species were collected in the 1950s and 1960s. Only three specimens date from after the year 2003, two of these from inside the Tsingy de Bemaraha National Park, the third from Beanka forest. The species is present in two protected areas: the Tsingy de Bemaraha Strict Nature Reserve and the adjacent Tsingy de Bemaraha National Park, which have been protected since 1927. But, except for the inaccessible tsingy, the reserves are threatened by fires which are set each year in the dry season in order to favour the growth of young grass for the grazing of cattle (Nicoll \& Langrand 1989; Rasoloarison \& Paquier 2008). Habitat loss as a result of bush fires is also a serious threat for $\mathrm{H}$. leandrii outside the protected areas. Considering these threats and the fact that the species is distributed in only five locations, H. leandrii is assessed as Endangered (EN).

\section{Notes}

Only few specimens with mature flowers were collected. The length of the corolla tube is very variable. It would seem that well-developed flowers have a corolla tube of $20-25 \mathrm{~mm}$ long, as is the case in the other Homollea species. However, the type collection, coll. ignot. 4680-RN, shows flowers with short $(6-7 \mathrm{~mm})$ and longer $(16-22 \mathrm{~mm})$ corolla tubes. In Leandri, Capuron \& Razafindrakoto 2094 the corolla tubes are hardly longer than the calyx tube (corolla tubes $12-15 \mathrm{~mm}$ long). Even in specimens with mostly well-developed flowers, such as Leandri \& Saboureau 2757, rare shorter flowers can be found (corolla tube $16 \mathrm{~mm}$ vs $22-25 \mathrm{~mm}$ long in most flowers). 


\section{Homollea longiflora Arènes}

Figs 3, 6A

Notulae Systematicae 16: 16, f. 3 (1-8) (Arènes 1960). - Type: Madagascar, Mahajanga Province, Boeny Region, canton Tsaramandroso, district Ambato-Boeni, N de Bevazaha, 8 Feb. 1949 (fl), Saboureau 7 (holo-: P; iso-: P, TAN, isotypes labelled as coll. ignot. 1857-RN).

\section{Other material studied}

MADAGASCAR: Mahajanga Province: Boeny Region, Réserve Naturelle Intégrale d'Ankarafantsika, Station Forestière d'Ampijoroa, 14 May 1952 (fr), Coll. ignot. 4952-SF (P); district Morovoay, Réserve Naturelle Intégrale d'Ankarafantsika, Station Forestière d'Ampijoroa, trail C towards Jardin Botanique, 200 m, 24 Jan. 2000 (fl), Davis, Rakotonasolo \& Wilkin 2504 (BR, K); Réserve Naturelle Intégrale d'Ankarafantsika, Station Forestière d'Ampijoroa, Jardin Botanique, section B, 9 Feb. 1999 (fl, fr), De Block \& Rakotonasolo 767 (BR, G, K, MO, P, TAN, WAG); Réserve Naturelle Intégrale d'Ankarafantsika, Station Forestière d'Ampijoroa, Jardin Botanique, section B, 9 Feb. 1999 (fl), De Block \& Rakotonasolo 768 (BR, G, K, MO, P, TAN, WAG); Réserve Naturelle Intégrale d'Ankarafantsika, Station Forestière d'Ampijoroa, Jardin Botanique, section A, 10 Feb. 1999 (fl), De Block \& Rakotonasolo 781 (BR, K, MO, P, TAN, WAG); Réserve Naturelle Intégrale d'Ankarafantsika, Station Forestière d'Ampijoroa, 3 km N d'Andranofasika, 12 Apr. 1984 (fr), Dorr \& Koenders 3017 (K, MO, P, WAG); Réserve Naturelle Intégrale d'Ankarafantsika, Station Forestière d'Ampijoroa, 2 Feb. 1972 (fl), Jacquemin 908 (P); Réserve Naturelle Intégrale d'Ankarafantsika, Station Forestière d'Ampijoroa, 15 Feb. 1973 (fl), Jacquemin 1223 (P); Réserve Naturelle Intégrale d'Ankarafantsika, Station Forestière d'Ampijoroa, edge of Ankarafantsika plateau, trail around lake, 75 m, 14 Feb. 1987 (fr), Nicoll 378 (K, MO, P, TAN, WAG); Réserve Naturelle Intégrale d'Ankarafantsika, Station Forestière d'Ampijoroa, edge of Ankarafantsika plateau, 100 m, 15 Feb. 1987 (fr), Nicoll 400 (K, MO, P, TAN); Ambato-Boina, Andranofasika, Parc National d'Ankarafantsika, E of lac Ravelobe, 28 Jan. 2007 (fr), Ralimanana, Andriamampandry, Rapanarivo \& Raharison 826 (BR, K, MO, P, TAN, TEF); Bevazaha, canton Tsaramandroso, district Ambato-Boeni, 8 Feb. 1949 (fl), Ramamonjisoa 1857-RN (P, TAN); Ankarafantsika, 6 Feb. 2000 (fl), Thulin, Kornhall, Popp \& Rivolala 10382 (UPS); Bongolava Region, Bongolava, 18 Mar. 2010 (fr), De Block, Groeninckx \& Rakotonasolo 2341 (BR, TAN).

\section{Description}

Small tree or shrub, up to $5 \mathrm{~m}$ tall; vegetative and reproductive parts glabrous (externally); young shoots brown, smooth; older shoots reddish brown, glossy, flaking. Leaves with petioles $0.5-1.5 \mathrm{~cm}$ long; blades narrowly elliptic or narrowly ovate, $(5.5-) 7-12 \times(1.3-) 1.7-3(-4) \mathrm{cm}$, coriaceous, drying glossy and greenish brown or, more rarely, brown above, glossy and somewhat paler below; apex acuminate or, more rarely, acute, acumen $0.3-1.2 \mathrm{~cm}$ long; base attenuate; secondary veins $7-12$ on each side of midrib; ciliate pit domatia sometimes present; stipules $0.5-1 \mathrm{~cm}$ long, basal cone $1.5-2.5 \mathrm{~mm}$ long, free parts of sheaths $2.5-5 \mathrm{~mm}$ long, triangular with acute tips. Inflorescences 3-12-flowered; peduncle $1.5-13.5 \mathrm{~cm}$ long; first order axes up to $2 \mathrm{~mm}$ long, rarely up to $35 \mathrm{~mm}$ long; first order bracts consisting of 1-2 $\mathrm{mm}$ high, triangular sheaths (but up to $5 \mathrm{~mm}$ high and keeled in case of long first order axes) and blades linear, narrowly elliptic, narrowly ovate or, more rarely, ovate, $0.3-3.5 \times 0.1-1.5 \mathrm{~cm}$ with attenuate bases and 3-6 mm long petioles or, more rarely, similar in size and shape to the vegetative leaves; higher order bracts usually absent, if present, then linear, 3-4 $\mathrm{mm}$ long; bracteoles absent. Flowers sweetly scented, shortly pedicellate, pedicels $2-8 \mathrm{~mm}$ long; calyx tube $1-2 \mathrm{~mm}$ long, glabrous and without colleters inside; calyx lobes $4.5-10 \times 0.3-0.75(-1) \mathrm{mm}$, not ciliate at the base outside, glabrous inside, tips rounded; corolla tube (10-)22-30 mm long, moderately villose in the upper half inside; corolla lobes $8-11 \times 2-3 \mathrm{~mm}$, tips obtuse to rounded; anthers $4.5-5.5 \mathrm{~mm}$ long, only the tips (1-2 $\mathrm{mm}$ ) exserted from the corolla tube at anthesis, inserted ca $2 \mathrm{~mm}$ below the level of the throat, white; ovary 1-2 mm long, sometimes faintly ribbed longitudinally (when dry); 3-7 ovules per locule; 


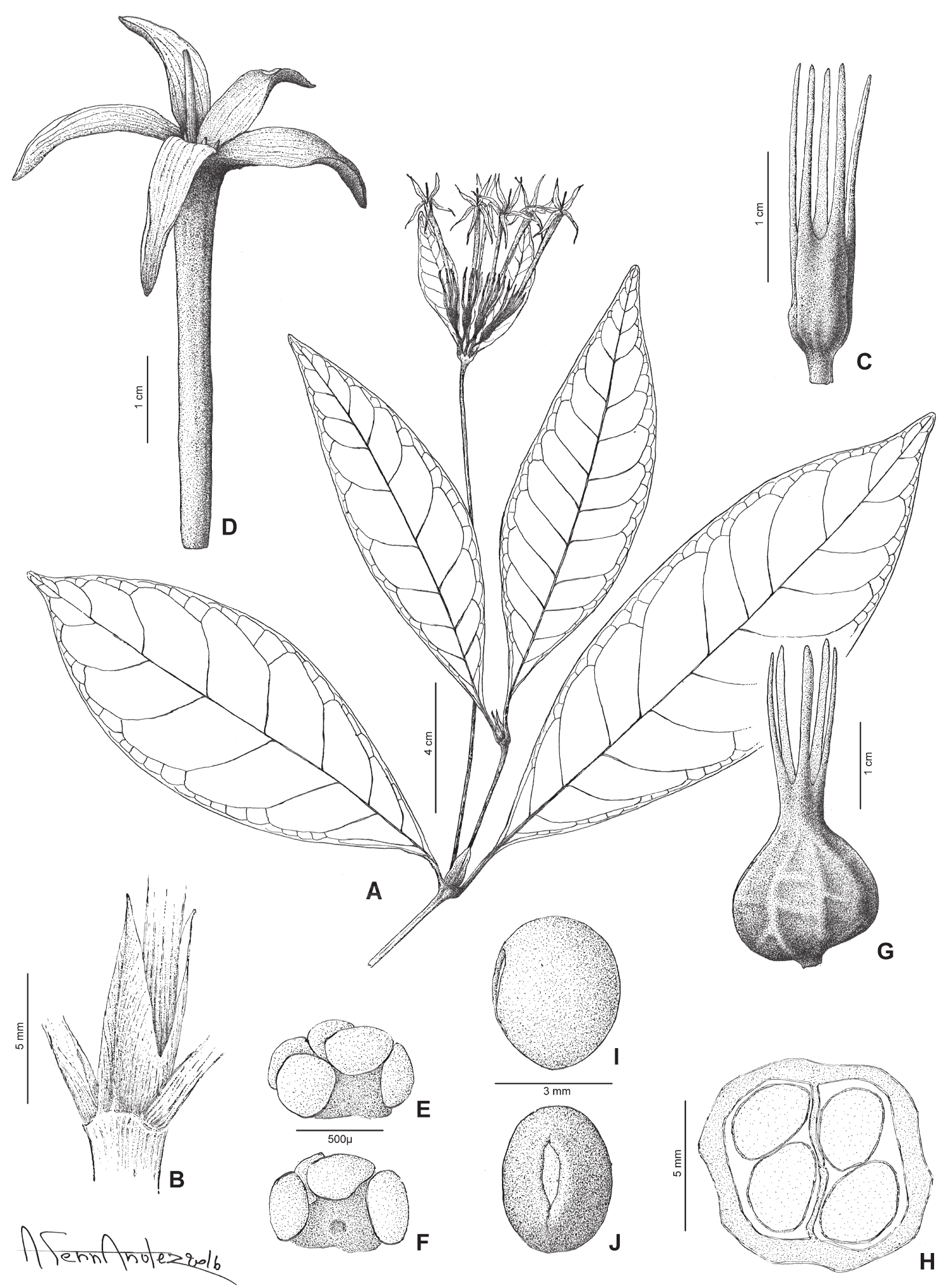

Fig. 3. Homollea longiflora Arènes. A. Flowering branch. B. Stipules. C. Ovary and calyx. D. Corolla, stamens, style and stigma. E. Placenta with ovules, abaxial view. F. Placenta with ovules, adaxial view. G. Fruit. H. Transverse section through fruit. I. Seed, lateral view. J. Seed, adaxial view. Drawn by Mr. A. Fernandez. A, C-D from Saboureau 7 (P); B, H-J from De Block et al. 2341 (BR); E-F from De Block et al. 768 (BR); G from Dorr \& Koenders 3017 (MO). 
stigma exserted from corolla tube for $4-6 \mathrm{~mm}$ at anthesis, receptive zone $15-25 \mathrm{~mm}$ long. Fruits 4-6 $\times 7-8 \mathrm{~mm}$ (persistent calyx not included); pyrene thin, crustaceous, without preformed germination slits; septum not stony; seeds $2-6$ per fruit, $3.5-4.5 \times 2.5-3 \mathrm{~mm}$.

\section{Distribution}

Known from Mahajanga Province in western Madagascar, centred in the Boeny Region with one collection from the Bongolava Region; mostly collected from the Ankarafantsika Reserve and surroundings (Fig. 6A).

\section{Habitat and phenology}

Lowland dry semideciduous or deciduous forest; on sandy soil, alt. 0-200 m. Flowering: JanuaryFebruary, with peak in February; fruiting: March-May.

\section{IUCN status}

Endangered: EN B1ab(iii) + 2ab(iii). The extent of occurrence (EOO) of $H$. longiflora is estimated to be $1,209 \mathrm{~km}^{2}$ and its area of occupancy (AOO) $36 \mathrm{~km}^{2}$ using a cell width of $3 \mathrm{~km}$. All collecting localities fall within the Ankarafantsika National Park and the Bongolava New Protected Area (created in 2006). The major threat for this species is habitat loss since both protected areas are under threat by logging for charcoal and timber, burning for grazing and slash-and-burn agriculture (Nicoll \& Langrand 1989). The sandy soil, once denuded, erodes quickly and vegetations do not recover. The distribution of this species is insufficiently known since all but three of the 15 specimens available at this time are from the Ankarafantsika National Park (mostly from the Ampijoroa Forest station near Lake Ravelobe), an area easily accessible to collectors. Considering the threats, and the fact that the species is distributed in only three locations, H. longiflora is assessed as Endangered (EN).

\section{Note}

The holotype, Saboureau 7, bears a handwritten label by Saboureau. Duplicates are available at P and TAN (with similar handwritten labels), but are labelled as coll. ignot. 1857-RN.

\section{Homollea perrieri Arènes}

Figs 4, 6B

Notulae Systematicae 16: 15, f. 3 (14-20) (Arènes 1960). - Type: Madagascar, Mahajanga Province, Boeny Region, Manongarivo, Ambongo, Jan. 1904 (fl, fr), Perrier de la Bâthie 3633 (holo-: P; iso-: P).

\section{Other material studied}

MADAGASCAR: Mahajanga Province: Betsiboka Region, forêt de Kasijy, Kelifely, Nov. 1974 (fl), Morat 4700 (P, TAN); Boeny Region, Majunga, 30 Mar. 1912 (fr), Afzelius 259 (P); Soalala, Réserve Naturelle Intégrale de Namoroka, ca $40 \mathrm{~km} \mathrm{~S}$ of Soalala, 3 Feb. 2000 (fr), Davis, Rakotonasolo \& Wilkin 2529 (BR, K, TAN); Majunga, dunes, Feb. 1915 (fl, fr), Perrier de la Bâthie 3504 (P); Ambongo, 17 Feb. 1841 (fr), Pervillé 680 (P); Réserve Naturelle Intégrale de Namoroka, canton Andranomavo, district Soalala, 2 Mar. 1952 (fr), Rakotovao 4067-RN (P, TAN, TEF).

\section{Description}

Shrub 1-4 m tall; vegetative and reproductive parts pubescent with trichomes $0.2-0.5 \mathrm{~mm}$ long (the longest trichomes occurring on ovary and fruit); young shoots brown, densely hirsute; older shoots fawn, greyish or dull brown, glabrous. Leaves with petioles $0.2-0.8 \mathrm{~cm}$ long, densely hirsute; blades narrowly elliptic, narrowly obovate, linear or, more rarely, elliptic or obovate, (3-)5.5-17 × $0.8-4 \mathrm{~cm}$, 


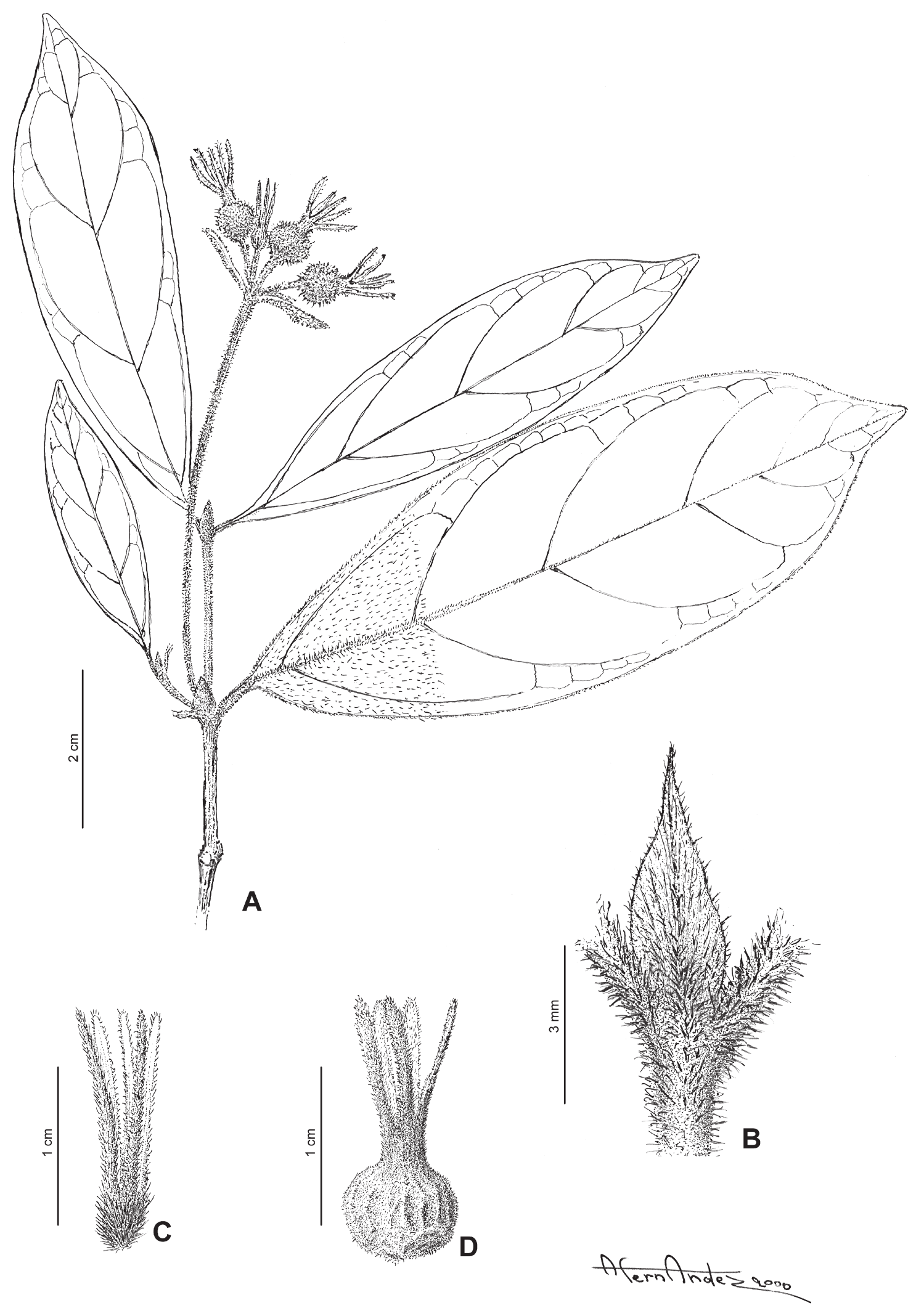

Fig. 4. Homollea perrieri Arènes. A. Fruiting branch. B. Stipules. C. Ovary and calyx. D. Fruit. Drawn by Mr. A. Fernandez. A, C-D from Afzelius 259 (P); B from Perrier de la Bâthie 3633 (P). 
subcoriaceous to coriaceous, drying somewhat glossy and brown or greenish above, somewhat paler below, moderately to densely hirsute, scabrid or \pm glabrous with trichomes restricted to the veins above, densely hirsute below; margins ciliate; apex acuminate or, more rarely, acute, acumen $0.2-$ $0.6 \mathrm{~cm}$ long; base attenuate or cuneate; secondary veins 5-10 on each side of midrib; ciliate pocket domatia sometimes present; stipules $0.3-0.8 \mathrm{~cm}$ long, sparsely to moderately hirsute outside, basal cone $1.5-4 \mathrm{~mm}$ long, free parts of sheaths $2-4 \mathrm{~mm}$ long, ovate with acuminate tips, acumen up to $2 \mathrm{~mm}$ long. Inflorescences 3-12-flowered, with peduncle, axes and pedicels densely hirsute; peduncle $0.5-9 \mathrm{~cm}$ long; first order axes up to $5 \mathrm{~mm}$ long; first order bracts consisting of 1-2 $\mathrm{mm}$ high triangular sheaths and blades linear, elliptic or ovate, $0.4-3.5 \times 0.1-1.5 \mathrm{~cm}$ with cuneate or attenuate bases and $1.5-3 \mathrm{~mm}$ long petioles; higher order bracts usually absent, if present, then linear, 2-4 $\mathrm{mm}$ long; bracteoles absent. Flowers shortly pedicellate, pedicels $1-6 \mathrm{~mm}(1-3 \mathrm{~mm}$ long in flowering stage, up to $6 \mathrm{~mm}$ long in fruiting stage); calyx tube (1.5-)2-2.5 mm long, moderately to densely hirsute outside, sparsely to moderately sericeous just below the lobes (further down hairs sparse or almost absent) and without colleters inside; calyx lobes $5-8(-10) \times 0.3-0.8 \mathrm{~mm}$, sparsely to moderately hirsute outside, inside moderately sericeous at the base, higher up pubescence identical to that on outside, margins ciliate, tips usually obtuse to rounded (rarely acute); corolla tube 15-20 mm long, moderately to densely hirsute outside, sparsely to moderately villose in the upper third inside; corolla lobes $8-11 \times 2 \mathrm{~mm}$, sparsely to moderately hirsute outside, sparsely to moderately sericeous at the base and glabrous higher up inside, margins ciliate; tips obtuse to rounded; anthers 4-6 mm long, exserted for most of their length but their bases included in the corolla tube at anthesis, inserted ca $1 \mathrm{~mm}$ below the level of the throat; ovary (1-)1.5-2 mm long, densely hirsute; $2-3$ ovules per locule; stigma exserted from corolla tube for 4-7 mm at anthesis, receptive zone 15-16 mm long. Fruits $4-6 \times 6-8 \mathrm{~mm}$ (persistent calyx not included), moderately to densely hirsute; pyrene stony, breaking up into 4 valves along 4 preformed longitudinal germination slits (two along the lines of fusion of the two locules and two perpendicular to those); septum not stony; seeds $2-4$ per fruit, $3-4 \times 2-3 \mathrm{~mm}$.

\section{Distribution}

Known from the Boeny and Betsiboka Regions in western Madagascar (Mahajanga Province), collected from the surroundings of Mahajanga and Ambongo and from the Namoroka and Kasijy Reserves (Fig. 6B).

\section{Habitat and phenology}

Lowland dry semideciduous or deciduous forest, on sandy soil, from the upper level of the beach to limestone formations further inland, alt. 0-200 m. Flowering: November-January; fruiting: FebruaryMarch.

\section{Vernacular name}

Dingadingana (Rakotovao 4067-RN).

\section{IUCN status}

Endangered: EN B2ab(iii). The extent of occurrence (EOO) of H. perrieri is estimated to be $10,176 \mathrm{~km}^{2}$, and its area of occupancy (AOO) $54 \mathrm{~km}^{2}$ using a cell width of $3 \mathrm{~km}$. Over a period of ca 175 years (first collection in 1841 by Pervillé) only seven specimens were collected: four specimens were collected before 1915, three between 1950 and 1975, the most recent specimen dates from the year 2000. The older specimens do not have detailed locality data, e.g., Majunga or Ambongo, which renders the assessment somewhat less reliable. The species occurs in five localities, three of which are in protected areas: Tsingy de Namoroka National Park, Kasijy Reserve and Mahavavy Kinkony New Protected area (created in 2015). The main threat to the species is decline of its habitat both inside and outside the protected areas as a result of logging for timber and charcoal, burning for grazing and slash-and- 
burn agriculture. Considering these threats, and the fact that the species occurs in only five locations, H. perrieri is assessed as endangered (EN).

\section{Notes}

In the protologue, Arènes (1960) described the flowers of $H$. perrieri as having a corolla tube of $11 \mathrm{~mm}$ long and corolla lobes of $5 \mathrm{~mm}$ long. Very few mature flowers are available for study (one on the isotype Perrier de la Bâthie 3633 and old, incomplete flowers in the envelopes on Morat 4700 and Perrier de la Bâthie 3504). None of these flowers show the measurements given by Arènes (1960). Their corolla tubes range between 15 and $20 \mathrm{~mm}$ and the corolla lobes between 8 and $10 \mathrm{~mm}$ long.

One specimen, Morat 4700, has long, linear leaves (up to $17 \times 0.8 \mathrm{~cm}$ ), whereas the other specimens have shorter wider leaves $(5-12 \times 1.2-4 \mathrm{~cm})$. The specimen Morat 4700 occurs in the southernmost locality for the species.

Homollea septentrionalis De Block, sp. nov. urn:lsid:ipni.org:names:77177486-1

Figs 5, 6B

\section{Diagnosis}

Homollea septentrionalis sp. nov. is similar to $H$. perrieri in that the young stems, petioles, leaves, stipules, inflorescence parts, ovary, calyx and corolla are pubescent. It differs from $H$. perrieri by the longer trichomes $((0.3-) 0.5-1.5 \mathrm{~mm}$ vs $0.2-0.5 \mathrm{~mm})$, the longer calyx lobes $((9-12-) 17-25 \mathrm{vs}$ $5-8(-10) \mathrm{mm})$, the longer corolla tubes and lobes $(20-27$ and $13-18 \mathrm{~mm}$, respectively, vs $15-20$ and $8-11 \mathrm{~mm})$ and by the higher number of ovules per locule (4-6 vs $2-3)$.

\section{Etymology}

The specific epithet refers to the distribution area of the species in the northernmost part of Madagascar.

\section{Type material}

Madagascar, Antsiranana Province, Sava Region, sous-préfecture de Vohemar, commune rurale de Daraina, Daraina, forêt d'Ampondrabe, à $1220 \mathrm{~m}$ du point côté 594, au 185', $338 \mathrm{~m}, 14 \mathrm{Feb} .2005$ (fl), Nusbaumer \& Ranirison 1468 (holo-: G scan; iso-: BR).

\section{Other material studied}

MADAGASCAR: Antsiranana Province: Diana Region, forêt de Sahafary, bassin de la Saharenena, 7 Nov. 1966 (fl), Capuron 24489-SF (P, TEF); Antsiranana II, Antsampano, Beately, Antsisinala, 11 Aug. 2005 (fr), Rakotonasolo \& Rapanarivo 1033 (BR, K, TAN); Irodo, Sahafary forest, 118 m, 4 Jan. 2008 (fl), Rakotonasolo \& Nowak 1147 (BR, K, TAN); Sava Region, Vohemar district, Daraina commune, Daraina, Bekaraoka South, 9 Apr. 2008 (fr), Bremer, Mouly, Ravelonarivo \& Kainulainen 5125 (S); sous-préfecture de Vohemar, commune rurale de Daraina, Daraina, forêt de Bekaraoka, partie Sud, 1,2 km S du point côté 330, 150 m, 16 Mar. 2003 (fr), Gautier, Wohlhauser \& Nusbaumer 4410 (G, K); Vohemar, Ampisikina, Tsaratanana, forêt d'Ampondrabe, à $1 \mathrm{~km}$ au NW du village d'Ambaribe, $200 \mathrm{~m}$, 4 Nov. 2005 (fr), Rakotonandrasana, Ratovoson, Guittou \& Jaovelo 965 (CNARP n.v., G, MO n.v., P n.v., TAN n.v.); sous-préfecture de Vohemar, commune rurale de Daraina, Daraina, forêt de Bekaraoka, partie Sud, à $1000 \mathrm{~m}$ du point côté 237, au 40, 160 m, 16 Mar. 2005 (fr), Ranirison \& Nusbaumer 961 (BR, G scan). 


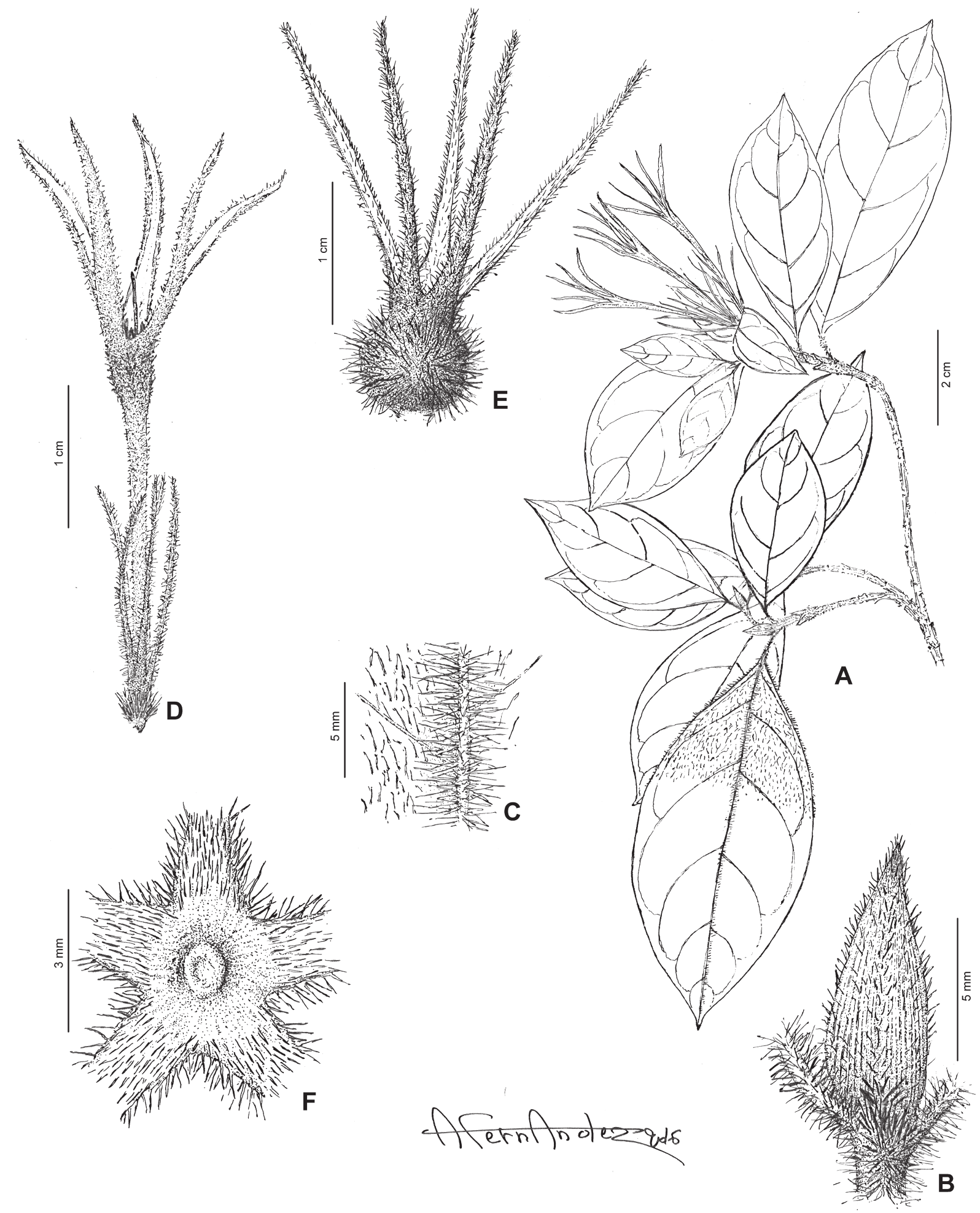

Fig. 5. Homollea septentrionalis De Block sp. nov. A. Flowering branch. B. Stipule. C. Detail of lower surface of leaf, showing pubescence on midrib and blade. D. Flower. E. Fruit. F. Apical view of disc and pubescent adaxial surface of calyx tube and lobes (base only). Drawn by Mr. A. Fernandez. A-D from Nusbaumer \& Ranirison 1468 (BR); E-F from Ranirison \& Nusbaumer 961 (BR). 


\section{Description}

Shrub 1-2 $\mathrm{m}$ tall; vegetative and reproductive parts pubescent with trichomes $(0.3-) 0.5-1.5 \mathrm{~mm}$ long (the longest trichomes occurring on ovary and fruit); young shoots reddish brown, densely hispid; older shoots reddish brown, flaking, glabrous. Leaves with petioles $0.5-1 \mathrm{~cm}$ long, densely hispid; blades elliptic, rarely ovate or obovate, $5-11 \times 2.5-5 \mathrm{~cm}$, subcoriaceous or rarely coriaceous, drying greenish or brownish above, discolourous or somewhat paler below but sometimes young leaves drying blackish on both surfaces, moderately to densely hispid or villose or rarely \pm glabrous with trichomes restricted to the veins above, densely hispid below; margins ciliate; apex acuminate, acumen $0.3-0.8 \mathrm{~cm}$ long; base cuneate to obtuse or, more rarely, unequal; secondary nerves 5-9 on each side of midrib; higher order veins sometimes dark or blackish brown in young leaves; domatia absent or inconspicuous; stipules $0.6-1 \mathrm{~cm}$ long, at the base densely hispid and higher up sparsely to moderately villose or, more rarely, \pm glabrous outside, margins ciliate, basal cone $2.5-5 \mathrm{~mm}$ long, free parts of sheaths $2.5-5 \mathrm{~mm}$ long, triangular with acute tips or, more rarely, ovate with acuminate tips, acumen up to $2 \mathrm{~mm}$ long. Inflorescences 3-12-flowered, with peduncle, axes, pedicels and bracts densely hispid; peduncle 1-2(-4.5) cm long; first order axes up to $2 \mathrm{~mm}$ long; first order bracts consisting of 1-2 $\mathrm{mm}$ high triangular sheaths and blades sessile or subsessile, broadly ovate to ovate, $0.8-3.5 \times 0.5-2.5 \mathrm{~cm}$ with cordate or truncate bases; higher order bracts usually absent, if present, then linear, up to $5 \mathrm{~mm}$ long; bracteoles absent. Flowers scented, sessile or subsessile; calyx tube 1-1.5 mm long, moderately to densely hispid outside, densely sericeous and without colleters inside; calyx lobes $(9-12-) 17-25 \times 0.5-0.8 \mathrm{~mm}$, sparsely to moderately hispid outside, inside densely sericeous in the basal $5 \mathrm{~mm}$, higher up pubescence identical to that on the outside, margins ciliate, tips acute; corolla tube 20-27 mm long, sparsely to moderately hirsute and with up to $5 \mathrm{~mm}$ long longitudinal lines of appressed hairs below the sinuses of the corolla lobes outside, moderately villose in the upper half inside; corolla lobes $13-18 \times 2 \mathrm{~mm}$, sparsely to moderately hirsute outside, sparsely to moderately sericeous at the base and glabrous higher up inside, margins ciliate, tips obtuse or acute; anthers $4.5-5 \mathrm{~mm}$ long, mostly included in the corolla tube at anthesis (only ca $1 \mathrm{~mm}$ exserted), inserted ca $3 \mathrm{~mm}$ below the level of the throath; ovary ca $2 \mathrm{~mm}$ long, densely hispid; 4-6 ovules per locule; stigma exserted from corolla tube for 4-5 mm at anthesis, receptive zone ca $14 \mathrm{~mm}$ long. Fruits ca $9 \times 9 \mathrm{~mm}$ (persistent calyx not included), moderately to densely hispid; pyrene stony, breaking up into 4 valves along 4 preformed longitudinal germination slits (two along the lines of fusion of the two locules and two perpendicular to those); septum not stony; seeds ca 5 per fruit, ca $4.5 \times 2.5-3 \mathrm{~mm}$.

\section{Distribution}

Only known from the Diana and Sava Regions in northern Madagascar (Antsiranana Province; Fig. 6B).

\section{Habitat and phenology}

Lowland dry semideciduous or deciduous forest, on sandy soil; alt. 150-350 m. Flowering: NovemberFebruary; fruiting: March-August.

\section{IUCN status}

Endangered: EN B1ab(iii) + 2ab(iii). The extent of occurrence (EOO) of H. septentrionalis sp. nov. is estimated to be $3,495 \mathrm{~km}^{2}$, and its area of occupancy (AOO) $54 \mathrm{~km}^{2}$ using a cell width of $3 \mathrm{~km}$. Seven of the eight known specimens are recent (collected after the year 2003) and are the result of the intensified collection effort made in this region mainly by the Conservatoire \& Jardin Botaniques de la Ville de Genève. The species occurs in five localities, two of which fall within the Loky-Manambato New Protected Area (Daraina), created in 2005 and managed by a Madagascan non-governmental organization, Association Fanamby. The main threat to the species is loss of habitat as a result of subsistence farming, logging for timber and charcoal and fires. Furthermore, the region is also subject to traditional mining for gold (Rakotondravony 2009; Nusbaumer et al. 2010). Considering these treats, 
and the fact that the species occurs in only five locations, $H$. septentrionalis sp. nov. is assessed as Endangered (EN).

\section{Note}

The specimens Bremer et al. 5125, Gautier et al. 4410, Nusbaumer \& Ranirison 1468, Rakotonandrasana et al. 965 and Ranirison \& Nusbaumer 961 have long and narrow calyx lobes, 17-25 mm long. As such, they are clearly different from $H$. perrieri, the calyx lobes of which vary in length between 5 and 8(-10) mm. The specimens Capuron 24489-SF, Rakotonasolo \& Rapanarivo 1033 and Rakotonasolo \& Nowak 1147 have shorter calyx lobes, ranging in length between 9 and $12 \mathrm{~mm}$. Their other characters, however, are identical to those of the typical specimens of $H$. septentrionalis sp. nov.: reddish brown shoots (vs fawn, greyish or dull brown in $H$. perrieri), trichomes $(0.3-) 0.5-1.5 \mathrm{~mm}$ long (vs $0.2-0.5 \mathrm{~mm}$ long) and sessile or subsessile flowers (vs pedicels 2-6 mm long). Furthermore, with the exception of Bremer et al. 5125, they possess the subsessile, broadly ovate or ovate blades of the first order bracts with cordate to truncate base typical for $H$. septentrionalis sp. nov. (vs shortly petiolate, linear, elliptic or ovate blades with cuneate or attenuate base in $H$. perrieri). The three specimens also share the same distribution area as the typical specimens of $H$. septentrionalis sp. nov. and are, for all these reasons, considered to belong to this species.

\section{Unplaced material}

A single specimen, coll. ignot. 25309-SF, from Mitsinjo near Mahajanga (Mahajanga Province, Boeny Region) shows characters intermediate between $H$. perrieri and $H$. septentrionalis sp. nov. The blades of the first order bracts are petiolate with a cuneate base and the flowers are shortly pedicellate as in $H$. perrieri. But the shoots are reddish brown and the specimen is densely pubescent with long trichomes, which are characters of $H$. septentrionalis sp. nov. The length of the calyx lobes is ca $9 \mathrm{~mm}$, which is in

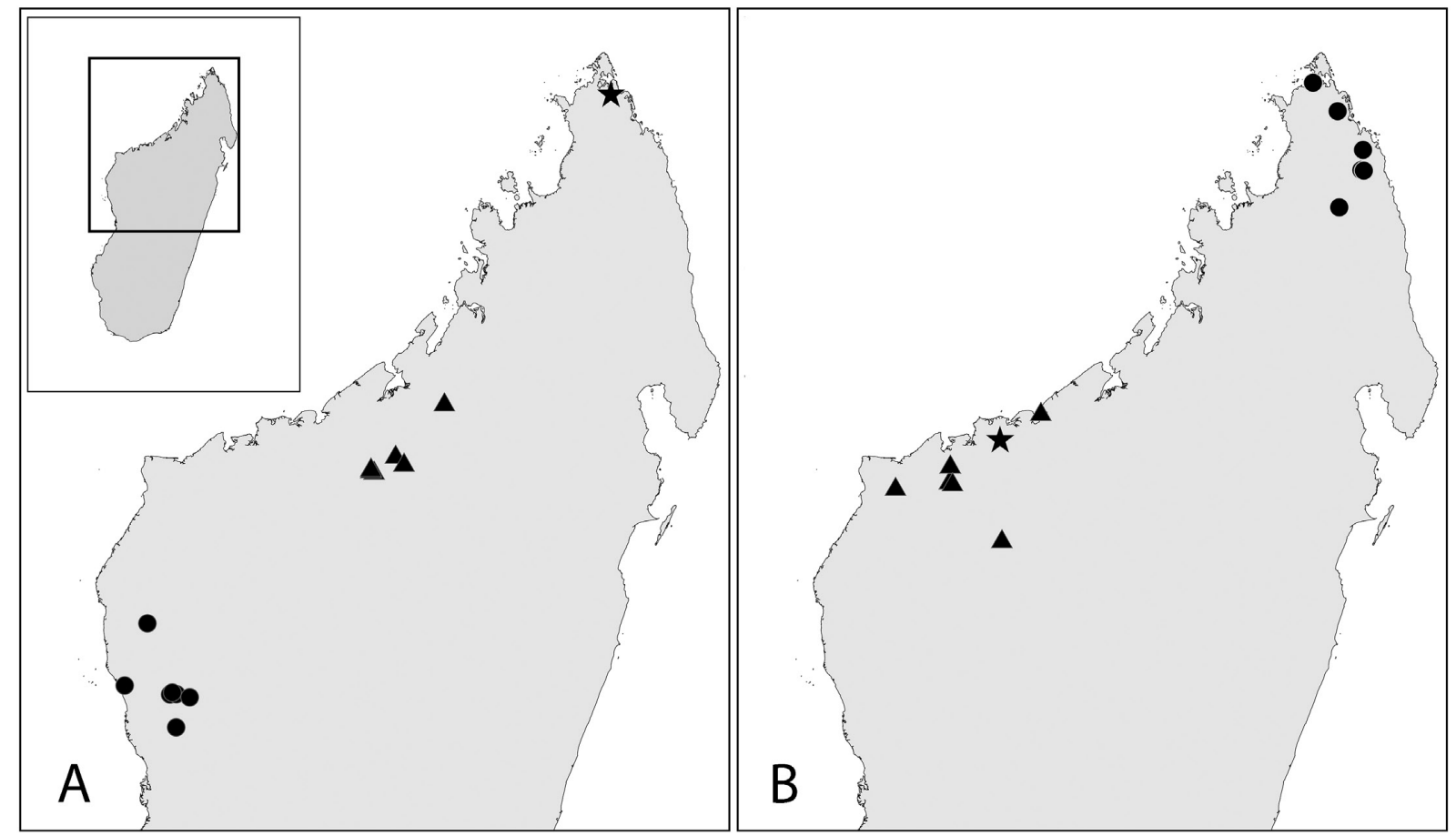

Fig. 6. Distribution maps of Homollea. A. H. furtiva De Block, sp. nov. ( $\star$ ), H. leandrii Arènes (•) and $H$. longiflora Arènes $(\mathbf{\Delta})$. B. H. perrieri Arènes $(\mathbf{\Delta})$, H. septentrionalis De Block sp. nov. $(\bullet)$ and unplaced material coll. ignot. 25309-SF ( $\star$ ). 
the upper region of the calyx lobe length in $H$. perrieri and the lower limit in $H$. septentrionalis sp. nov. But the pyrene structure is different from that in both $H$. perrieri and $H$. septentrionalis sp. nov. It resembles the one in $H$. leandrii, breaking up into dispersal units consisting of part of the pyrene wall and part of the stony septum, each containing a single seed. With just a single specimen available, no decision can be made on the taxonomic status of this taxon. However, this specimen may well represent a sixth species of Homollea.

\section{Material studied}

MADAGASCAR: Mahajanga Province: forêt d'Ambihiko, $12 \mathrm{~km} \mathrm{SW}$ de Mitsinjo, canton Mitsinjo, 11 Jul. 1965 (fr), Coll. ignot. 25309-SF (P, TEF) (Fig. 6B).

\section{Discussion}

Many newly described Madagascan Rubiaceae species are based on recently collected plant material. This is also the case for the two new species described here: Homollea furtiva sp. nov. is only known from two specimens collected in 2004 and 2007; H. septentrionalis sp. nov. is known from seven specimens collected after 2003, and a single older one collected in 1966. The five species of the genus Homollea are narrow endemics. This is certainly part of the reason for the low numbers of specimens collected. Also, some species occur in difficultly accessible areas, e.g., H. leandrii in Tsingy de Bemaraha, H. perrieri in Tsingy de Namoroka, but this is not the case for others, e.g., H. longiflora in Ankarafantsika Reserve and H. furtiva sp. nov. in Montagne des Français. It is clear that, even taking into account the recent increase in collecting effort by institutes such as Missouri Botanical Garden, Royal Botanic Gardens Kew and Conservatoire \& Jardin Botaniques de la Ville de Genève, further intensive collecting is necessary throughout Madagascar in the remaining primary vegetation as well as in all remnant vegetation fragments.

Being narrow endemics, the five Homollea species are more vulnerable to extinction risk than widespread species (IUCN 2001). Because of their restricted distribution range (Area of Occupancy), their presence in five or less locations and a continuing decline in extent and/or quality of habitat, the IUCN assessment for H. leandrii, H. longiflora, H. perrieri and H. septentrionalis sp. nov. is Endangered. Homollea furtiva sp. nov., which is only present in one location in a protected area, is assessed as Critically Endangered. All five Homollea species are represented in at least one protected area. Some of these protected areas, such as, e.g., Montagne des Français, Loky-Manambato and Bongolava, have only been recently created and lack strong protection. But all protected areas in Madagascar are in danger of encroachment by anthropogenic actions, such as tavy agriculture, fires to improve grazing land, logging for timber and charcoal, traditional mining, etc. (Nicoll \& Langrand 1989; Hartley et al. 2007; Goodman et al. 2008; Draper 2010; Innes 2010). Protected areas have little financial means, few staff and resources and are unable to stop the encroachment (Nicoll \& Langrand 1989; Hannah et al. 2008; Wingen 2011). Occurrence in protected areas therefore does not constitute a guarantee for low extinction risk.

All Homollea species occur in limestone areas or on calcareous soil. Homollea furtiva sp. nov., H. leandrii and $H$. perrieri occur in limestone massifs, Montagne des Français, Tsingy de Bemaraha, and, Tsingy de Namoroka and the Kasijy massif, respectively. Homollea longiflora and H. septentrionalis sp. nov. are linked with calcareous soils in the Ankarafantsika and the Loky-Manambato regions, respectively. Ankarafantsika lies on a calcareous plateau which is covered by sandy soil. Loky-Manambato is a mosaic of different habitats varying in elevation, climate, precipitation and soil types. Part of the region has calcareous soils (Nusbaumer et al. 2010; Lourenço \& Goodman 2013). Du Puy \& Moat (1998) stressed the influence of rock type on species distribution. The strongest correlation between rock type and species distribution is found for limestone: species on limestone are often restricted to this rock type, whereas widespread species may occur on a range of different rock types but are usually absent 
from limestone (Du Puy \& Moat 1998). This correlation between limestone or calcareous soils and narrow endemism is also known outside Madagascar (Wong et al. 2002). Because of the presence of high numbers of narrow endemics, the limestone areas in Madagascar deserve additional collecting and stronger conservation efforts.

The genus Homollea shows great variation in the structure of the pyrenes. In all species, two pyrenes are present, their abaxial surface formed by the endocarp, which may be thin and crustaceous or thick and stony, and their adaxial surface formed by the septum, which may be membranous or stony. The two pyrenes, each comprising one to three seeds, enclose separate areas in the fruit, but remain joined to each other on their adaxial side. Thin crustaceous pyrenes without opening mechanism occur in H. longiflora (Fig. $3 \mathrm{H}$ ) and H. furtiva sp. nov. The adaxial surface of the pyrenes (the septum) remains membranous and it is the fruit or the two joined pyrenes that function as dispersal unit. Stony pyrenes occur in the three other species of the genus. Here too, the two pyrenes remain joined on their adaxial side. They open easily along 4 preformed longitudinal germination slits, two along the lines of fusion of the two locules and two perpendicular to those (Fig. $2 \mathrm{~F}-\mathrm{G}$ ). In H. perrieri and H. septentrionalis sp. nov. the septum, forming the adaxial surface of the pyrenes, remains membranous. The two joined pyrenes break up into four valves along the preformed germination slits, freeing the seeds, which seem to act as dispersal units. In H. leandrii a situation unique within the Pavetteae is found in that the dispersal units are formed by part of the pyrene, part of the septum and a single seed. The two joined stony pyrenes have the same four preformed germination slits as in H. perrieri and H. septentrionalis sp. nov. and open along these four slits. But instead of falling apart into four valves, each of the four pyrene parts remains connected to part of the stony septum. When the pyrenes break open each seed remains partly enclosed in a stony dispersal unit formed by part of the pyrene wall and part of the stony septum (Fig. 2H).

Further information is needed in order to better understand the different pyrene types and pyrene opening mechanisms in Homollea. Because of the fact that few collections with ripe fruits are available, it was not possible to perform many fruit dissections per species. The variation in pyrene type and pyrene opening mechanism are probably adaptations to the habitat in which Homollea species occur. But many of the Homollea specimens give little or no habitat data (especially historical collections) and, therefore, no hard conclusions can be drawn. It is possible that stony pyrenes and dispersal units are adaptations to prevent seed damage in the karst limestone areas. The presence of the opening mechanism could be a drought adaptation, allowing seeds to be freed rapidly after a period of rain.

\section{Acknowledgements}

I want to express my thanks to the herbarium curators of G, K, MO, P, S, TAN, TEF and WAG for providing loans of plant material and for allowing herbarium material to be studied during visits. Dr. L. Gautier and Dr. L. Nusbaumer are thanked for sending scans of herbarium material of $H$. septentrionalis sp. nov. and for exchanging ideas on its delimitation. Mr. A. Fernandez is gratefully acknowledged for preparing the illustrations. Dr. H. Engledow and Ms. L. Tytens are thanked for making the distribution maps. Dr. S. Ntore is gratefully acknowledged for help with the IUCN assessments. Two anonymous reviewers are thanked for constructive comments and useful suggestions on an earlier draft of this paper.

Field work was conducted within the framework of the 'Madagascar Research and Conservation Program' of Missouri Botanical Garden (1999) and the Kew Madagascar Conservation Centre (2010). I thank Dr. P. Lowry, as well as Mr. S. Cable and Dr. H. Ralimanana, for giving me access to the Missouri Botanical Garden (MBG) and the Kew facilities, respectively. The Madagascan teams of MBG and Kew are gratefully acknowledged for their help and hospitality. I thank Madagascar National Parks (formerly ANGAP) for permission to collect in the protected areas in Madagascar. Several botanists of the Parc Botanique et Zoologique de Tsimbazaza (PBZT), Dr. F. Rakotonasolo, Dr. S. Rapanarivo and Ms. J. Razanatsoa, were of invaluable help during field work. Financial support for field work was provided 
by the Research Foundation - Flanders (FWO), the 'Stichting tot Bevordering van Wetenschappelijk Onderzoek in Afrika' and the Percy Sladen Memorial Fund.

\section{References}

Anonymous 1962. Systematics Association committee for descriptive biological terminology. II. Terminology of simple symmetrical plane shapes (chart 1). Taxon 11: 145-156. https://doi.org/10.2307/1216718

Arènes J. 1960. A propos de quelques genres Malgaches de Rubiacées. Notulae Systematicae 16: 6-19.

Bachman S., Moat J., Hill A.W., de la Torre J. \& Scott B. 2011. Supporting Red List threat assessments with GeoCAT: geospatial conservation assessment tool. ZooKeys 150: 117-126.

https://doi.org/10.3897/zookeys.150.2109

Baillon H.N. 1879. Observations sur les Naucléées. Adansonia, ser. 1, 12: 311-316.

Beentje H. 2012. The Kew Plant Glossary. An illustrated dictionary of plant terms. Royal Botanic Gardens, Kew.

Bridson D.M. \& Robbrecht E. 1985. Notes on the tribe Pavetteae (Rubiaceae). Bulletin $d u$ Jardin botanique national de Belgique 55: 83-115. https://doi.org/10.2307/3668012

Callmander M.W., Schatz G.E. \& Lowry P.P. II. 2005. IUCN Red List assessment and the Global Strategy for Plant Conservation: taxonomists must act now. Taxon 54: 1047-1050.

https://doi.org/10.2307/25065491

Callmander M.W., Schatz G.E., Lowry P.P. II, Laivao M.O., Raharimampionona J., Andriambololonera S., Raminosoa T. \& Consiglio T.K. 2007. Identification of priority areas for plant conservation in Madagascar using Red List criteria: rare and threatened Pandanaceae indicate sites in need of protection. Oryx 41: 168-176. https://doi.org/10.1017/S0030605307001731

Callmander M.W., Phillipson P.B., Schatz G.E., Andriambololonera S., Rabarimanarivo M., Rakotonirina N., Raharimampionona J., Chatelain C., Gautier L. \& Lowry P.P. II. 2011. The endemic and non-endemic vascular flora of Madagascar updated. Plant Ecology and Evolution 144: 121-125.

https://doi.org/10.5091/plecevo.2011.513

Capuron R. 1973. Révision des Rubiacées de Madagascar et des Comores. Unpublished manuscript: notes regroupées et mises en forme par J. Bosser, dactylographiées de F. Chauvet. Laboratoire de Phanérogamie, Paris.

Davis A.P., Govaerts R., Bridson D.M., Ruhsam M., Moat J. \& Brummitt N.A. 2009. A global assessment of distribution, diversity, endemism, and taxonomic effort in the Rubiaceae. Annals of the Missouri Botanical Garden 96: 68-78. https://doi.org/10.3417/2006205

Davis A.P., Rakotonasolo F. \& De Block P. 2010. Coffea toshii sp. nov. (Rubiaceae) from Madagascar. Nordic Journal of Botany 28: 134-136. https://doi.org/10.1111/j.1756-1051.2010.00710.x

De Block P. 1997. Biosystematic studies in the tribe Pavetteae (Rubiaceae - Ixoroideae). PhD thesis, University of Antwerp, Belgium.

De Block P. 2003a. New combinations in the genus Paracephaelis (Pavetteae, Rubiaceae). Systematics and Geography of Plants 73: 99-100.

De Block P. 2003b. Robbrechtia, a new Rubiaceae genus from Madagascar. Systematic Botany 28: $145-156$.

De Block P. 2014. Eight new species of Ixora (Ixoreae - Rubiaceae) from Madagascar. Plant Ecology and Evolution 147: 237-255. https://doi.org/10.5091/plecevo.2014.927 
De Block P. \& Robbrecht E. 1998. Pollen morphology of the Pavetteae (Rubiaceae, Ixoroideae) and its taxonomic significance. Grana 37: 260-275. https://doi.org/10.1080/00173139809362678

De Block P., Degreef J. \& Robbrecht E. 2001. Reinstatement of the Afro-Malagasy genus Coptosperma (Rubiaceae, Ixoroideae, Pavetteae). Systematics and Geography of Plants 71: 455-492. https://doi.org/10.2307/3668694

De Block P., Razafimandimbison S.G., Janssens S., Ochoterena H., Robbrecht E. \& Bremer B. 2015. Molecular phylogenetics and generic assessment in the tribe Pavetteae (Rubiaceae). Taxon 64: 79-95. https://doi.org/10.12705/641.19

Draper E. 2010. The pierced heart of Madagascar. National Geographic 218: 80-109.

Du Puy D.J. \& Moat J.F. 1998. Vegetation mapping and classification in Madagascar (using GIS): implications and recommendations for the conservation of biodiversity. In: Huxley C.R., Lock J.M. \& Cutler D.F. (eds) Chorology, taxonomy and ecology of the African and Madagascan floras: 97-117. Royal Botanic Gardens, Kew.

Ferm J., Kårehed J., Bremer B. \& Razafimandimbison S.G. 2016. Paracarphalea, a new genus of the coffee family segregated from the Malagasy endemic genus Carphalea (Rubiaceae, Rubioideae, Knoxieae). Phytotaxa 263: 98-112. https://doi.org/10.11646/phytotaxa.263.2.2

Goodman S.D., Cremen C., Langrand O., Dolch R., Rasolandrasana B., Grenfell S., Cardiff S.G., Befourouack J., Rasoloarison V., Paquier F., Sorg J.-P., Ganzhorn J.U., Kappeler P.M., Ratsirason J., Durbin J., Rakotoniaina L.J., Andrianandrasana H.T. \& Randriamahefasoa J. 2008. Protection de la nature. In: Goodman S.D. (ed.) Paysages naturels et biodiversité de Madagascar: 515-654. Publications scientifique du Museum, Paris.

Govaerts R., Ruhsam M., Andersson L., Robbrecht E., Bridson D.M., Davis A.P., Schanzer I. \& Sonké B. 2016. World Checklist of Rubiaceae [online]. Available from http://apps.kew.org/wcsp/ [accessed Oct. 2016].

Hannah L., Dave R., Lowry P.P.II, Andelman S., Andrianarisata M., Andriamaro L., Cameron A., Hijmans R., Kremen C., MacKinnon J., Randrianasolo H.H., Andriambololonera S., Razafimpahanana A., Randriamahazo H., Randrianarisoa J., Razafinjatovo Ph., Raxworthy C., Schatz G.E., Tadross M. \& Wilmé L. 2008. Climate change adaptation for conservation in Madagascar. Biology Letters 4: 590 594. https://doi.org/10.1098/rsbl.2008.0270

Hartley A.J., Nelson A., Mayaux P. \& Grégoir J.-M. 2007. The assessment of African protected areas. JRC Scientific and Technical Research series: EUR 22780 EN.

http://dopa.jrc.ec.europa.eu/sites/default/files/AssessmentOfAfricanProtectedAreas_EUR22780.pdf

Innes J. 2010. Madagascar rosewood, illegal logging and the tropical timber trade. Madagascar Conservation and Development 5: 6-10. https://doi.org/10.4314/mcd.v5i1.57335

IPNI 2012. The International Plant Names Index [online]. Available from http://www.ipni.org [accessed Oct. 2016].

IUCN 2001. IUCN Red List Categories and Criteria. Version 3.1. IUCN, Gland, Switzerland and Cambridge, UK.

IUCN 2016. Guidelines for using the IUCN Red List Categories and Criteria. Version 12. Prepared by the Standards and Petitions Subcommittee [online]. Available from http://www.iucnredlist.org/documents/RedListGuidelines.pdf [accessed Feb. 2017].

Leenhouts P.W. 1968. A guide to the practice of herbarium taxonomy. International Bureau for Plant Taxonomy and Nomenclature of the International Association for Plant Taxonomy, Utrecht. 
Lourenço W.R. \& Goodman S.M. 2013. A synopsis of the scorpion fauna of the Loky-Manambato (Daraina) region in Madagascar. Revista Ibérica de Aracnología 22: 47-58.

Moat J. \& Smith P. (eds) 2007. Atlas of the vegetation of Madagascar. Royal Botanic Gardens, Kew.

Nicoll M.E. \& Langrand O. 1989. Madagascar: Revue de la conservation et des aires protegées. World Wide Fund for Nature, Gland.

Nusbaumer L., Ranirison P., Gautier L., Chatelain C., Loizeau P.-A. \& Spichiger R. 2010. LokyManambato: point de rencontre des principales unités phytogéographiques de Madagascar. In: Van der Burgt X., Van der Maesen J. \& Onana J.-M. (eds) Systématique et Conservation des Plantes Africaines: 253-264. Royal Botanic Gardens, Kew.

Rakotondravony H.A. 2009. Reptiles, amphibiens et gradient altitudinal dans la région de Daraina, extrême nord-est de Madagascar. Malagasy Nature 2: 52-65.

Rasoloarison V. \& Paquier F. 2008. Les tsingy de Bemaraha. In: Goodman S.D. (ed.) Paysages naturels et biodiversité de Madagascar: 585-593. Publications scientifique du Museum, Paris.

Robbrecht E. 1988. Tropical woody Rubiaceae: Characteristic features and progressions. Contributions to a new subfamilial classification. Opera Botanica Belgica 1. National Botanic Garden of Belgium, Meise.

Schatz G.E., Lescot M., Rogers Z., Sikes K., Andriambololonera S., Raharimampionona J. \& Wolf A.-E. 2003. Gazetteer to Malagasy Botanical Collecting Localities [online]. Available from http://www.mobot.org/MOBOT/Research/madagascar/gazetteer/ [accessed Jun.-Aug. 2016].

Thiers B. continuously updated. Index Herbariorum: A global directory of public herbaria and associated staff. New York Botanical Garden's Virtual Herbarium. Available from http://sweetgum.nybg.org/science/ih/ [accessed Sep. 2016]

Wingen A.C. 2011. Environmental protection in Madagascar: an evaluation of program viability. Msc Thesis, Hubert H. Humphrey School of Public Affairs, U.S.A.

Wong T., Hamilton-Smith E., Chape S. \& Friederich H. (eds) 2002. Proceedings of the Asia-Pacific Forum on Karst Ecosystems and World Heritage, Gunung Mulu National Park World Heritage Area, Sarawak, Malaysia, 26-30 May 2001. Australian Department of the Environment and Heritage, Canberra.

Manuscript received: 21 September 2016

Manuscript accepted: 23 March 2017

Published on: 5 April 2018

Topic editor: Koen Martens

Desk editor: Connie Baak

Printed versions of all papers are also deposited in the libraries of the institutes that are members of the EJT consortium: Muséum national d'Histoire naturelle, Paris, France; Botanic Garden Meise, Belgium; Royal Museum for Central Africa, Tervuren, Belgium; Natural History Museum, London, United Kingdom; Royal Belgian Institute of Natural Sciences, Brussels, Belgium; Natural History Museum of Denmark, Copenhagen, Denmark; Naturalis Biodiversity Center, Leiden, the Netherlands; Museo Nacional de Ciencias Naturales-CSIC, Madrid, Spain; Real Jardín Botánico de Madrid CSIC, Spain. 